\title{
Block, Stephen R.: Social Work and Boards of Directors: The Relationship Model
}

\section{Raquel Rego}

VOLUNTAS: International Journal of Voluntary and Nonprofit

Organizations

Official journal of the International

Society for Third-Sector Research

ISSN 0957-8765

Voluntas

DOI 10.1007/s11266-016-9729-9

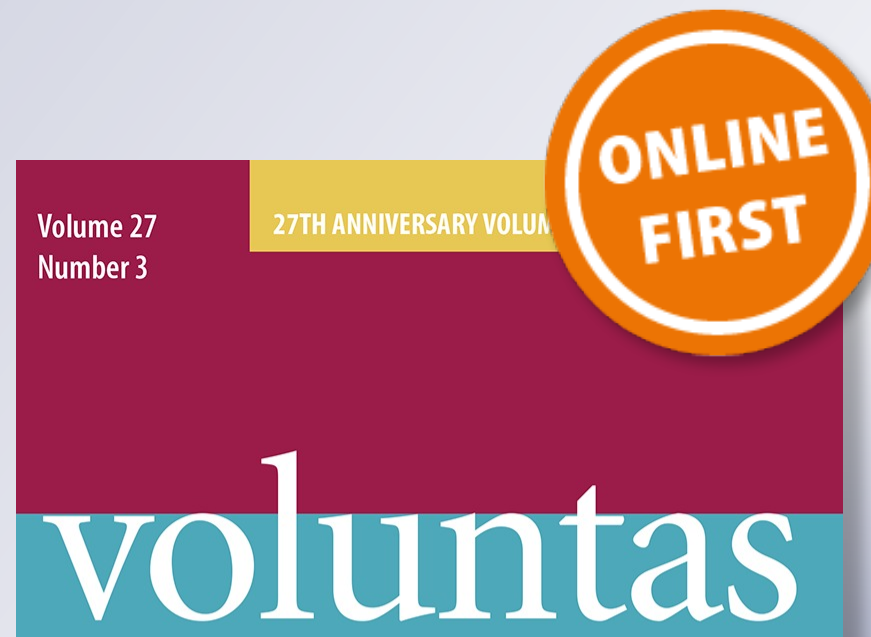

International Journal of Voluntary and Nonprofit Organizations

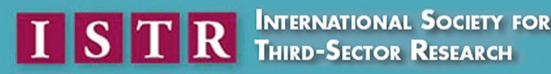

Springer

$11266 \cdot$ ISSN 0957-8765

27(3) 1021-1514 (2016)

Springer 
Your article is protected by copyright and all rights are held exclusively by International Society for Third-Sector Research and The Johns Hopkins University. This e-offprint is for personal use only and shall not be selfarchived in electronic repositories. If you wish to self-archive your article, please use the accepted manuscript version for posting on your own website. You may further deposit the accepted manuscript version in any repository, provided it is only made publicly available 12 months after official publication or later and provided acknowledgement is given to the original source of publication and a link is inserted to the published article on Springer's website. The link must be accompanied by the following text: "The final publication is available at link.springer.com". 


\title{
Block, Stephen R.: Social Work and Boards of Directors: The Relationship Model
}

\section{Lyceum Books Inc., Chicago, 2016, pp. 195, references, index, about the author, $\$ 36.95$}

\author{
Raquel Rego 1
}

(C) International Society for Third-Sector Research and The Johns Hopkins University 2016

Stephen R. Block has a deep involvement with the nonprofit sector: he has been working, teaching, and publishing on nonprofit organizations for decades. He started his career as a social worker and has always been related with this profession, which has been significantly increasing based on the number of professionals. This background gives him singular credibility with regard to the specific subject of this book, especially considering that he uses an approach of combining scientific communication with informal learning.

Block wrote this book enthused by the perception of the preparedness of professionals who assume the executive director role, that is, who experience a "metamorphosis" (p.vii), also known as the Peter Principle. The aim of his book is to provide a model for executive directors to use to achieve long-term success in relationships with boards of directors.

The book starts with a problem raised by a former student of Block's that is not solved until the end, and this immediately informs the reader about the style and purpose of the book: a clear and easy guide for new managers. Most of the chapters begin with an abstract, include a bullet list in the middle, and provide a summary or conclusion at the end. An index also contributes to locating the main contents, although it does have some limitations (for instance, Kurt Lewin, Cyril Houle, and John Carver have no entries even though they are all important in the theoretical debate).

The author proposes a model to frame the relationships between executive directors, a full-time job carried out by professionals who assume the daily

Book Review Editor: Silvia Ferreira.

Raquel Rego

raquel.rego@ics.ulisboa.pt

1 Instituto de Ciências Sociais - Universidade de Lisboa, Av. Prof. Aníbal de Bettencourt, 9, 1600-189 Lisbon, Portugal 
management of nonprofit organizations, and boards of directors, a voluntary role in nonprofit organizations carried out by individuals with legal responsibility and decision-making power. Block first presents the traditional and policy government models, showing that they are hierarchical, based on controlling tasks, and lacking in relational communications; these models face difficulties relating to board members and their attributed tasks. In contrast to the dominant models, Block proposes the relationship model, which underlines the importance of the human element and of lowering or at least revising expectations.

The relationship model is based on the idea that the interdependence between people is the starting point in relationships even when they also entail formal obligations and legal responsibilities. This model highlights the importance of managing communication strategies and encouraging trusting relationships to achieve effective cooperation. This can also be achieved with simple gestures such as sharing a meal after a work meeting, which the author explains.

Block focuses on a process that has gained relevance with the professionalization of the nonprofit sector. Although this book is not the first time that the author has approached the subject, in this book, he does so in an in-depth and unprecedented way. His proposed model is not completely new to considering that it mainly adapts already known theories, in particular Carl Rogers' theory on the human element, which the author discusses along with Helen Harris Perlman's reflections on relationships in social work and other contributions. The relationship model presents one main limitation: it is not a prescriptive tool, as the author observes, and it is possible that a reader might feel a lack of systematization (in chapters 6 and 8, in particular) that would allow for effective adoption.

The book is addressed to social workers, both students and practitioners, who become executive directors, but it can be useful to all professionals in the same situation and to all executive directors and boards of directors considering that the differences in the roles may be ambiguous. However, researchers may also find the book interesting because it brings awareness to organizational problems and provides an opportunity to learn about the specificities of social work in the American context.

Some issues deserve further consideration in future work, such as executive directors' various involvements and their durations at non-profit organizations, which leads us to consider that more interchange between different scientific traditions and national systems would be beneficial for the debate, particularly between the Anglo-Saxon and French approaches to professionalization in the nonprofit world.

Acknowledgments The author receive financial support from FCT - UID/SOC/50013/2013. 